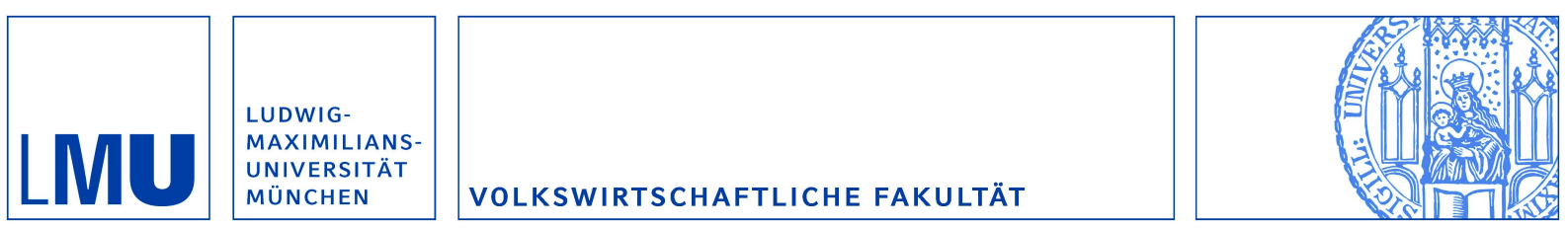

Bauer, Christian und Langenmayr, Dominika:

Sorting into Outsourcing: Are Profits Taxed at a Gorilla's Arm's Length?

Munich Discussion Paper No. 201 1-15

Department of Economics

University of Munich

Volkswirtschaftliche Fakultät

Ludwig-Maximilians-Universität München

Online at https://doi.org/10.5282/ubm/epub. 12312 


\title{
Sorting into Outsourcing: Are Profits Taxed at a Gorilla's Arm's Length?
}

\author{
Christian J. Bauer, Dominika Langenmayr \\ University of Munich, Department of Economics, Seminar for Economic Policy \\ Akademiestr. 1/II, 80799 München \\ christian.bauer@lrz.uni-muenchen.de,dominika.langenmayr@lrz.uni-muenchen.de
}

\begin{abstract}
This article analyzes profit taxation according to the arm's length principle in a new model where heterogeneous firms sort into foreign outsourcing. We show that multinational firms are able to shift profits abroad even if they fully comply with the tax code. This is because, in equilibrium, intra-firm transactions occur in firms that are better than the market at input production. Transfer prices set at market values following the arm's length principle thus systematically exceed multinationals' marginal costs. This allows for a reduction of tax payments with each unit sold. The optimal organization of firms hence provides a new rationale for the empirically observed lower tax burden of multinational corporations.
\end{abstract}

Key words: outsourcing, profit taxation, transfer pricing, arm's length principle, multinational firms

JEL: F23, L22, H25

\footnotetext{
"We thank Carsten Eckel, Hartmut Egger, Aart Gerritsen, Andreas Haufler, Christian Keuschnigg, Gianmarco Ottaviano, Michael Pflüger, Jens Südekum, and seminar participants at the Universities of Munich, Passau, and Augsburg, the 2011 International Trade Workshop in Göttingen, and the 2011 annual congresses of the International Institute of Public Finance in Ann Arbor and the Association for Public Economic Theory in Bloomington for valuable comments.

Financial support from the German Research Foundation (Bauer) and the Bavarian Graduate Program in Economics (Langenmayr) is gratefully acknowledged.
} 


\section{Introduction}

Multinational firm activity has become one of the most striking features of the global economy. Multinational enterprises (MNEs) now account for a major share of economic activity around the world. Some of these firms have an economic power similar to a middle-income country. General Electric, for example, which is active in over 100 countries, earned revenues of 182 billion US-Dollars in 2008, more than the GDP of a medium-sized economy like Chile.

Such enterprises are not only big, but also highly productive and profitable. ${ }^{1}$ They are consequently very attractive for governments, as they not only provide jobs and investments, but their high profits also offer the opportunity to generate tax revenue. However, there are widespread concerns that MNEs' profits are especially hard to tax, as - due to their internationality - they can avoid taxation in high-tax countries. Anecdotal evidence supports this claim: In 2008, the car manufacturer BMW, who has split production among various facilities in and outside Europe, effectively paid 6\% tax on its income in Germany, where its headquarters are located. In the same year, on average, German corporations paid $30 \%$ of their earnings as profit taxes. ${ }^{2}$ Recent empirical evidence substantiates this phenomenon. Egger et al. (2010b), for example, find that in European high-tax countries, subsidiaries of multinational corporations pay over $30 \%$ less tax than similar domestically-owned firms.

In this article, we contribute to the literature that aims to explain lower tax payments of MNEs. This literature has established that MNEs are able to shift profits to low-tax locations by manipulating transfer prices and/or intra-firm debt. We provide a new and complementary explanation by showing that even correct application of transfer prices (which are determined according to the arm's length principle) may imply profit shifting and lower taxes for MNEs if their optimal organizational choice is taken into account.

We develop this result in a model where firms source an input from a foreign country

\footnotetext{
${ }^{1}$ For empirical evidence on the superior productivity of MNEs see, among others, Head and Ries (2003) and Helpman et al. (2004).

${ }^{2}$ See the financial statements of BMW (2008, p. 11) and, for average tax payments in Germany, Deutsche Bundesbank (2011, p. 22).
} 
either by producing it in a fully-owned subsidiary or by purchasing it on the (foreign) market. Firms differ in their ability to produce the input in a subsidiary. In equilibrium, only the firms that are the most productive in input production engage in vertical foreign direct investment (FDI) and become a MNE.

In this model, we then explore the implications of profit taxation. We explicitly model the determination of transfer prices according to the arm's length principle. This principle, which is prevalent worldwide, implies that intra-firm transactions have to be valued at arm's length, i.e. as if the transaction had taken place between independent parties. In practice, market prices of comparable transactions are used. However, only those firms that are better at producing the input than the market do so themselves. Therefore, the market (and transfer) price systematically exceeds the marginal cost of input production within the multinational firm. The arm's length at which intra-firm transactions are taxed exceeds the intended length - profits are taxed, metaphorically speaking, at a gorilla's, not a human's, arm's length. ${ }^{3}$

If firm profits are taxed according to the exemption system, taxation at this "gorilla's arm's length" has several implications for firm behavior. ${ }^{4}$ Due to the elevated transfer price, multinational firms can shift some profits abroad with each unit produced. Compared to a no-tax benchmark, they therefore set lower prices to increase quantities. Furthermore, the reduced tax burden constitutes an additional incentive to become a MNE. All in all, this shows that some profit shifting of MNEs is a feature inherent in the tax system, and that even correct application of the arm's length principle implies that MNEs pay lower taxes than purely domestic firms.

\footnotetext{
${ }^{3} \mathrm{~A}$ gorilla's arms are about a foot $(\mathrm{ca} 30 \mathrm{~cm})$ longer than the arms of a human, even though an average gorilla is shorter than an average man.

${ }^{4}$ The exemption system is the predominant method to treat foreign profit income for taxation in the OECD. It has traditionally been applied by most continental European countries. Recently, the UK and Japan have also switched to this tax scheme. It is consistent with empirical evidence that the effects highlighted in this article arise only under the exemption method, and not in a tax credit system: For firms in the US (where the tax credit system is used), Desai et al. (2006) do not find a positive effect of the average tax rate of a firm in non tax haven countries on the probability to invest in a tax haven. For Germany, where profits are taxed according to the exemption method, Gumpert et al. (2011) however find a positive effect.
} 
Is this taxation at a gorilla's arm's length quantitatively important? In our model, the magnitude of the effect depends on the productivity difference between MNEs and firms that engage in foreign outsourcing. Tomiura (2007) finds in a large dataset of Japanese firms that firms which engage in FDI are on average 18\% more productive (as measured by value-added per worker) than firms who outsource input production. This suggests that there may be a substantive profit shifting effect due to productivity differences. ${ }^{5}$

Our paper relates to several strands of literature. First, there is a vast literature on profit shifting by multinational firms. Early theoretical contributions include, for example, Janeba (1996) or Haufler and Schjelderup (2000). Huizinga and Laeven (2008) provide empirical evidence that there is substantial profit shifting between European countries. ${ }^{6}$ Other empirical studies have focused on different methods of profit shifting. The use of intra-firm loans or adjustments of the capital structure to avoid taxation has been analyzed, among others, by Buettner et al. (2009) and Egger et al. (2010a). Furthermore, transfer prices, especially of intangible assets, have long been suspected to be manipulated for profit shifting (see Dischinger and Riedel (2011) and Clausing (2003), for example).

There is little theoretical literature on the tax implications of transfer pricing. Gresik and Osmundsen (2008) discuss how transfer prices are chosen in a vertically integrated industry when no arm's length price is observable. Also in the absence of an arm's length price, Elitzur and Mintz (1996) look at how a firm sets the transfer price when taking into account how the transfer price affects both incentives of the subsidiary's manager as well as the tax burden. Devereux and Keuschnigg (2009) explicitly consider the arm's length principle. Modeling the interaction between arm's length pricing and financial frictions, they find that even in the absence of taxes headquarters would like to choose elevated transfer prices to provide their subsidiaries with liquidity. None of these papers discusses the possibility that some profit shifting is possible even with perfect adherence to the arm's length principle.

\footnotetext{
${ }^{5}$ Tomiura (2007) obtains even stronger results for other measures of productivity, such as firm size or home market share (for which he finds productivity differences of factor 4.7 and 10.1, respectively).

${ }^{6}$ For a survey of the empirical literature see Devereux (2007).
} 
By developing a new and simple model of the decision to either buy the input on the market or become a MNE, our paper also contributes to the literature on the FDI-vs.outsourcing decision among heterogeneous firms (see Spencer (2005) for a survey). The bulk of this literature takes an incomplete contracts approach to the theory of the firm and focuses on contractual frictions between final goods producers and producers of specialized inputs; see, among others, Grossman and Helpman (2002), Antràs (2003), Antràs and Helpman (2004), and Grossman and Helpman (2005). The only paper that considers the interaction of taxes with the outsourcing decision is Egger and Seidel (2010). They show that the possibility to shift profits and lower the tax burden constitutes a reason to do FDI instead of outsourcing, and also provide empirical support for these findings. They do not, however, incorporate the arm's length principle in their analysis.

The remainder of this article is structured as follows. In the next section, we present the basic model. Section 3 derives the equilibrium in a benchmark case without taxation. Profit taxation is introduced in section 4 . Section 5 concludes.

\section{Model setup}

In this section, we present the basic framework of our model. We begin with a world without taxes, which serves as a benchmark below.

\subsection{General assumptions}

Consider a static world economy with two countries, labeled $H$ (a high-tax country) and $L$ (a low-tax country/tax haven), each endowed with a fixed amount of inelastically supplied, internationally immobile labor, the only factor of production. The two countries produce and trade a homogenous numeraire good $Y$. $H$ also produces a differentiated good $X$, for which firms source intermediate inputs from $L$.

In more detail, firms in the $X$ sector each produce a differentiated consumer good from a specific variety of a generic intermediate input and fixed overhead labor. Firms endogenously decide about the organization of production, choosing to either outsource or produce the input in a subsidiary. In the first case, they obtain a generic variant of the input on the foreign market and customize it within the firm. Alternatively, firms 
can produce a customized input in a fully-owned foreign subsidiary (FDI). ${ }^{7}$ The differentiated goods producers differ with respect to the quality of their FDI opportunities (i.e. their variable costs of input production in the subsidiary), which are exogenously assigned to them. This heterogeneity can be interpreted as being implied by the quality of the blueprint that a firm possesses, or as differences in the ability to implant these blueprints efficiently in a foreign subsidiary.

The $X$ sector is monopolistically competitive, while the $Y$ sector is perfectly competitive. There is free entry into product markets and free trade between $H$ and $L$ in inputs and in the $Y$ good. ${ }^{8}$ Firms in the $Y$ sector are homogenous, and thus earn zero profits. Choosing units so that one unit of the numeraire is produced from one unit of labor, wages are equal to unity in both countries. ${ }^{9}$

The sequence of events is the following. First, firms decide whether to enter into the product market based on their anticipated future profits. Second, $X$ sector firms organize optimally. Third, production and consumption occurs, and profits are realized.

\subsection{Consumers}

Consumers in $H$ are homogeneous and value the two (private) goods $X$ and $Y$. The preferences of a representative consumer are given by a log-linear utility function of the form

$$
U \equiv \mu \ln X+Y^{D}, X \equiv\left[\int_{i \in \Omega} x_{i}^{\frac{\sigma-1}{\sigma}} d i\right]^{\frac{\sigma}{\sigma-1}},
$$

where $Y^{D}$ is the quantity consumed of the numeraire good. $\Omega$ represents the set of available varieties in the monopolistically competitive sector. Varieties are consumed in

\footnotetext{
${ }^{7}$ Input production in a subsidiary in $H$ is also possible, but, as becomes clear below, yields no substantial insights in the benchmark model due to factor price equalization. This is because we design the model so that integrated firms are indifferent between producing in $H$ and $L$ when tax rates are identical across countries. When tax rates differ, however, they will strictly prefer the low-tax country, which will be $L$ in this model, justifying the environment described above.

${ }^{8}$ Allowing for trade in $X$ is also possible, but not necessary, and is therefore omitted for simplicity.

${ }^{9}$ Therefore, as there are no wage differentials, our model is one of FDI between similar (developed) countries. Indeed, this is one of the most common forms of FDI: Bernard et al. (2010) report that $74 \%$ of US imports from Japan are intra-firm; in contrast, the intra-firm trade share in US imports from Bangladesh is only $2 \%$.
} 
quantities $x_{i}$, where $i$ is the index for the variety and its seller. Varieties are substitutes and the elasticity of substitution between any pair of varieties is $\sigma$, with $1<\sigma(<\infty)$. The constant $\mu$ weighs the relative importance of the two goods and, due to the quasilinear preferences, is the sole determinant of total expenditures for $X .{ }^{10}$ As in Dixit and Stiglitz (1977), demand for each variety is isoelastic and given by

$$
x_{i}=\frac{\mu}{p_{i}^{\sigma}} P^{\sigma-1}
$$

where $p_{i}$ is the price of variety $i$ and $P \equiv\left[\int_{i \in \Omega} p_{i}^{-(\sigma-1)} d i\right]^{-\frac{1}{\sigma-1}}$ is the price index for good $X$. Denoting total income by $I$, the residual income yields the quantity consumed in $H$ of the numeraire good, $Y^{D}=I-\mu$.

\subsection{Firms}

There is a large pool of potential entrants into the $X$ sector. We normalize its mass to 1. ${ }^{11}$ Anticipating market conditions, each potential entrant chooses its optimal organizational structure ("make or buy") and, given this structure and the ensuing optimal output choice, decides whether to enter.

In the following, we characterize firms' objectives and their optimal decisions under each of the two alternative organizational forms, FDI and outsourcing.

FDI: Each firm has the option to become a MNE by acquiring or setting up a fullyowned foreign subsidiary. Operating this foreign plant requires a fixed cost $f>0$. Input production takes place at a firm-specific constant marginal cost $a_{i}$. These input coefficients are drawn from a distribution $G(a), a \in[\underline{a}, \bar{a}]$.

They are exogenously assigned to each firm and known at the time of market entry. ${ }^{12}$ The final assembly of the consumer good occurs at the headquarter in $H$; this requires

\footnotetext{
${ }^{10}$ Exploiting this simplifying result of quasi-linear preferences has become standard in the applied literature, see for example Chor (2009), Baldwin and Okubo (2009), Cole and Davies (2011), or Krautheim and Schmidt-Eisenlohr (2011).

${ }^{11}$ Assuming a given mass of potential entrants as part of the economy's endowment is common in the applied literature on heterogenous firms, see Baldwin and Okubo (2009) and Krautheim and Schmidt-Eisenlohr (2011), among others.

${ }^{12}$ If we think of $a_{i}$ representing the technological knowledge of firm $i$, the implicit assumption is that
} 
the headquarter to incur fixed costs $c>0$.

Profit maximization given demand (eq. (2)) results in standard mark-up pricing:

$$
p_{i}=\frac{\sigma}{\sigma-1} a_{i} .
$$

Maximized profits are equal to

$$
\pi_{i}=\left[p_{i}-a_{i}\right] x_{i}-c-f=\left[\frac{\sigma-1}{\sigma} \frac{P}{a_{i}}\right]^{\sigma-1} \frac{\mu}{\sigma}-c-f .
$$

More productive MNEs charge lower prices, thus sell larger quantities, and earn higher profits.

Outsourcing: Under outsourcing, the firm buys a non-specific variant of the input from a competitive stand-alone supplier in $L$ at an exogenous price $r .{ }^{13}$ This assumption introduces a unique market price for comparable transactions, which is the ideal world for the application of the arm's length principle below, where one market price determines the transfer price for all MNEs.

Outsourcing avoids the added fixed costs for operating a subsidiary, but the generic variant of the input needs to be customized to fit the differentiated good firm's specific requirements. ${ }^{14}$ To model these costs in a simple way, we assume that the firm has to buy $1+\tau$ units of the input in order to use one unit in production.

Since the market price for the input and customization costs are the same for all outsourcing firms, these firms charge identical profit-maximizing prices:

$$
p_{o}=\frac{\sigma}{\sigma-1}(1+\tau) r \text {. }
$$

this knowledge can be transferred completely and costlessly to the subsidiary. Alternatively, we may presume a matching process that pairs firms and potential foreign subsidiaries and think of $a_{i}$ as the match-specific unit production cost. For a more elaborate environment similar in spirit see Grossman et al. (2006).

${ }^{13}$ We take the existence and productivity of the intermediate input supplier as given and assume that demand of outsourcing firms in $H$ does not affect the world market price of the input. Furthermore, we make the implicit assumption that the subsidiary of the most productive firm does not sell to other final good producers, for example because its advantage lies only in producing the customized input. This assumption is discussed in more detail in section 4.3.

${ }^{14}$ For a similar approach where a standardized, market-bought input is less suited for the producer's specific purposes see, among others, Lorz and Wrede (2008). 
It follows that all outsourcing firms also sell the same quantities $x_{o}$ and earn the same profits $\pi_{o}$. Taking fixed costs $c$ in the headquarter into account, profits in the optimum are given by

$$
\pi_{o}=\left[p_{o}-(1+\tau) r\right] x_{o}-c=\left[\frac{\sigma-1}{\sigma} \frac{P}{(1+\tau) r}\right]^{\sigma-1} \frac{\mu}{\sigma}-c .
$$

From the point of view of an outside observer, all outsourcing firms behave identically, even though they are intrinsically heterogenous because their organizational outside options differ. ${ }^{15}$

It follows immediately from the presence of fixed costs that, for firms to optimally choose FDI over foreign outsourcing, variable costs of MNEs must fall short of variable costs of outsourcing, $(1+\tau) r$. This is the simple intuition behind our claim that MNEs pay relatively less tax than firms without foreign affiliates due to the use of market prices for the determination of transfer prices.

In principle, the presence of customization costs may imply that not all integrated firms exhibit variable costs below the market price of the input, $r$. Such firms (the smallest integrated firms) would optimally choose domestic integration, not FDI, as profit taxation would impose variable costs in excess of their true economic costs. To avoid the inconvenience of a case distinction between domestic and foreign integration, we focus on an industry where

$$
\tau \leq\left(\frac{c+f}{c}\right)^{\frac{1}{\sigma-1}}-1
$$

This set of parameters simplifies the exposition because, in equilibrium, all integrated firms are MNEs. Dropping this restriction would complicate the model without changing the implications of optimal organization for profit taxation at arms' length prices: that MNEs are able to shift profits abroad even if they adhere perfectly to the tax code.

\footnotetext{
${ }^{15}$ Since outsourcing firms have homogenous unit production costs and MNEs have heterogenous unit production costs, one can view our model as a hybrid of the Krugman (1980) model and the Melitz (2003) model.
} 


\section{Benchmark without taxation}

In equilibrium, sufficiently productive firms incur the added fixed cost of organizing a foreign affiliate and become MNEs. Less productive firms may always enter and realize $\pi_{o}$ by sourcing the input from the market. Since $\pi_{o}$ is decreasing in the mass of active firms, entry will drive the profits of outsourcing firms to zero. Combining (6) and $\pi_{o}=0$, this implies:

$$
P^{*}=\left(\frac{\sigma c}{\mu}\right)^{\frac{1}{\sigma-1}}(1+\tau) r \frac{\sigma}{\sigma-1} .
$$

The price index of the $X$ sector is fully determined by free entry into outsourcing (and thus independent of the distribution of productivities $G(a)) .{ }^{16}$ The price index is increasing in overhead costs because they reduce the mass of active firms; it is lower in larger markets (as measured by $\mu$ ), since a larger market induces additional firm entry. ${ }^{17}$ Moreover, if customization is more costly or input suppliers become less productive (an increase in $\tau$ or $r$ ), the price level rises, as varieties produced by outsourcing firms become more expensive.

Firms choose their mode of organization by comparing profits under outsourcing (eq. (6)) and vertical integration (eq. (4)). Since profits of MNEs are strictly decreasing in their own unit production costs, while profits are independent of these costs under outsourcing, only firms with $a_{i} \leq a^{*}$ profitably choose to become MNEs. The cutoff $a^{*}$ is thus uniquely determined by $\pi\left(a^{*}\right)=\pi_{o}$. In equilibrium, using (8), it is given by:

$$
a^{*}=\left(\frac{c}{c+f}\right)^{\frac{1}{\sigma-1}}(1+\tau) r .
$$

We summarize the properties of optimal organizational form in:

\footnotetext{
${ }^{16}$ How does the zero-profit condition of outsourcing firms determine the price index? Suppose some shock induces an additional MNE to enter the market. The added demand for overhead labor bids up the real wage $(1 / P)$ and, other things equal, reduces profits of all active firms. This causes some outsourcing firms to exit the market, so that the price index raises again. It does so up to its starting value, the only level compatible with zero profits of outsourcing firms.

${ }^{17}$ The C.E.S. price index can be interpreted as the price index of the optimized consumption bundle. As additional varieties increase consumers's options and thereby utility, more varieties imply a lower price index.
} 
Lemma 1 (Optimal organization). Firms with $a_{i}<a^{*}$ become MNEs while firms with $a_{i} \geq a^{*}$ source the input from the market. The cost cutoff $a^{*}$ for FDI is increasing in the cost level of input suppliers on the market $(r)$, in the necessary degree of customization $(\tau)$, and in the relative fixed cost of outsourcing vs. integration $(c /(c+f))$.

These properties are immediately intuitive. As the fixed costs of integration $(c+f)$ rise relative to those of an outsourcing firm $(c)$, outsourcing becomes more attractive. More firms are integrated if profits under outsourcing are lower, which is the case if the customization costs $(\tau)$ or the market price $(r)$ are higher.

Moreover, we conclude that the organizational form is robust to changes in the underlying productivity distribution of firms' production abilities. Innovations in the production technology, measured e.g. by a shift in the mean of $G(a)$, thus leave the cutoff for outsourcing unaffected. This is because, in our model, such changes are perfectly accommodated by entry into outsourcing. This feature, which comes without loss of generality for the general point that firms sort into FDI, allows for a particularly tractable solution.

We now turn to the variety of available products. The mass of varieties produced by MNEs is given by $1 \times G\left(a^{*}\right)$. We solve for the mass of outsourcing-firms $n_{o}^{*}$ as a function of the cutoff $a^{*}$ by combining the equilibrium price index, firms' pricing rules, and, after substituting for firm indices with their cost coefficients, the definition of the price index: ${ }^{18}$

$$
n_{o}^{*}=\frac{\mu}{\sigma c}-\left[\frac{(1+\tau) r}{\tilde{a}\left(a^{*}\right)}\right]^{\sigma-1},
$$

where we defined a harmonic mean of input coefficients of MNEs,

$$
\tilde{a}\left(a^{*}\right) \equiv\left[\int_{\underline{a}}^{a^{*}} a^{-(\sigma-1)} d G(a)\right]^{-\frac{1}{\sigma-1}} .
$$

The number of outsourcing firms increases in the size of the $X$ sector (as measured by $\mu$ ) and decreases in the organization cutoff $a^{*}$, which is endogenous and given in (9). Following an increase in fixed $\operatorname{costs} c$, the number of outsourcing firms active in the market falls, so that equilibrium profits are again consistent with free market entry.

\footnotetext{
${ }^{18}$ Substituting for firms $i$ with input coefficients $a$, the price index in the economy is given by $P=\left[n_{o}\left(p_{o}\right)^{-(\sigma-1)}+\int_{\underline{a}}^{a^{*}} p(a)^{-(\sigma-1)} d G(a)\right]^{-\frac{1}{\sigma-1}}$.
} 
To complete the characterization of equilibrium, we now solve for the outcome in the $Y$ sector. As noted above, due to the quasi-linear preference structure, demand for $Y$ is given by $Y^{D}=I-\mu{ }^{19}$ Income $I$ consists of labor income $l$ and profits, i.e. $I=l+\int_{\underline{a}}^{a^{*}}\left[p_{i} x_{i}-a_{i} x_{i}-c-f\right] d G(a)$. Thus, $Y^{D}$ is given by

$$
Y^{D}=\left[\frac{(1+\tau) r}{\tilde{a}\left(a^{*}\right)}\right]^{\sigma-1} c-(c+f) G\left(a^{*}\right)+l-\mu .
$$

A change in the organizational structure of the $X$ sector affects $Y^{D}$ via profit income. If the cutoff $a^{*}$ increases, there is a larger number of profitable MNEs, which implies a higher aggregate income, thus raising demand for $Y$. This effect is dampened by the additional fixed costs incurred by MNEs.

This completes the description of the benchmark case without taxes.

\section{Taxation}

We now introduce profit taxation into the model to address the stylized fact proposed in the introduction: that multinational firms pay systematically less tax (relative to their profits) than firms without foreign affiliates. The common explanation is that firms strategically misprice cross-border transactions (i.e. manipulate transfer prices or intra-firm debt) to shift profits into low-tax jurisdictions.

To policy makers and much of the academic literature, the ideal method to prevent these manipulation activities is the arm's length principle. ${ }^{20}$ This principle states that intra-firm transactions should be valued as if they had taken place between independent parties. It has been supposed that, if firms adhered perfectly to this principle, no profit shifting would take place. The low tax burden of MNEs would then originate from the ability of MNEs to circumvent the rules imposed by the arm's length principle.

In the following section, we offer an alternative explanation. We show that, due to sorting into outsourcing, MNEs are able to shift some profits abroad even if the arm's length principle is fully enforced.

\footnotetext{
${ }^{19}$ Note that $Y^{D}$ is not equal to the amount of $Y$ produced in the country $\left(Y^{S}\right)$, as some of the $Y$-goods must be exported in order to balance trade (inputs are imported from the other country).

${ }^{20}$ See, however, Devereux and Keuschnigg (2009).
} 


\subsection{Implementing the tax code in the model}

The arm's length principle is defined as the assessment of intra-firm transactions at the value that would have prevailed if the involved parties were not related. This value is not observable in reality; its determination is a task fraught with difficulty.

To approximate such a value it is common practice to identify comparable market transactions and impose the associated price for the valuation of transactions within the multinational corporation. The relevant price for taxation within a MNE is thus equal to the price that the firm would have had to pay to an unrelated party on the market.

We implement this practice in the model by setting the transfer price for taxation equal to the market price of the input, $r .{ }^{21}$ Assuming that foreign profits are exempt from taxation in the home country, the after-tax profit of a multinational firm is given by

$$
\pi_{i}^{t}=\left(1-t_{H}\right)\left(p_{i}^{t}-r\right) x_{i}^{t}+\left(1-t_{L}\right)\left(r-a_{i}\right) x_{i}^{t}-c-f
$$

where $t_{H}$ and $t_{L}\left(<t_{H}\right)$ are the domestic and the foreign profit tax rate, respectively, and after-tax profits can be repatriated without additional costs. For simplicity, we assume that fixed costs are not deductible. ${ }^{22}$ Substituting (2) into (13) and optimizing yields profit maximizing prices for each multinational: ${ }^{23}$

$$
p_{i}^{t}=\frac{\sigma}{\sigma-1}\left(\frac{1-t_{L}}{1-t_{H}} a_{i}-\frac{t_{H}-t_{L}}{1-t_{H}} r\right) .
$$

Arm's length taxation distorts MNEs' behavior as a combined result of the tax rate differential and firm heterogeneity.

\footnotetext{
${ }^{21}$ We use $r$, not $(1+\tau) r$, as the customization $\operatorname{costs} \tau$ arise in the production of the final consumer good. Setting the transfer price equal to $(1+\tau) r$ would strengthen the effects shown in the following section.

${ }^{22}$ This assumption, while not particularly realistic, is common in the literature, see e.g. Krautheim and Schmidt-Eisenlohr (2011). Our main results continue to hold if fixed costs are deductible, but assuming non-deductable fixed costs cuts out analytical complexity. The only qualitative difference of making fixed costs deductable is with respect to the price index, which then becomes independent of taxation.

${ }^{23}$ To guarantee positive prices, we make the following technical assumption on the lower bound of the support of $G(a): \underline{a}>\frac{t_{H}-t_{L}}{1-t_{L}} r$. This permits standard distributions like the bounded Pareto, uniform, and others.
} 
Turning to outsourcing firms, their profit function is now given by:

$$
\pi_{o}^{t}=\left(1-t_{H}\right)\left[p_{o}^{t}-(1+\tau) r\right] x_{o}^{t}-c
$$

Facing a pure tax on operating profits, the profit maximizing price is again given by its no-tax value in eq. (5) and equal for all outsourcing firms. Note, however, that since profit taxation impacts the prices of MNEs, it affects demand conditions of all active firms via the industry price level.

Finally, we assume that tax revenues are redistributed as a lump sum to the consumers. Note that this transfer does not affect aggregate demand in the $X$ sector, which is optimally equal to $\mu$ due to the quasi-linear preferences.

\subsection{Equilibrium with taxes}

Firms' optimal behavior depends on the industry price level, which is endogenous. The equilibrium condition that determines the price index is the zero-profit condition for outsourcing firms. From $\pi_{o}^{t}=0$, we solve for ${ }^{24}$

$$
P_{t}^{*}=\frac{\sigma}{\sigma-1}\left(\frac{1}{1-t_{H}} \frac{\sigma c}{\mu}\right)^{\frac{1}{\sigma-1}}(1+\tau) r=\left(\frac{1}{1-t_{H}}\right)^{\frac{1}{\sigma-1}} P^{*}
$$

Despite lower prices set by MNEs, the price index is higher than its no-tax benchmark value due to market exit. ${ }^{25}$ Using (16) allows us again to solve for the unique cost cutoff that determines the firm's optimal mode of production. Comparing after-tax profits under both organizational forms, firms choose to become multinationals if and only if $a_{i} \leq a_{t}^{*}$, where

$$
a_{t}^{*}=\frac{1-t_{H}}{1-t_{L}}(1+\tau) r\left(\frac{c}{c+f}\right)^{\frac{1}{\sigma-1}}+\frac{t_{H}-t_{L}}{1-t_{L}} r
$$

\footnotetext{
${ }^{24}$ To avoid double superscripts, we indicate equilibrium values of aggregates in the case with taxation with subscript $t$.

${ }^{25}$ As MNEs set lower prices, demand shifts from outsourcing firms to MNEs. Additionally, as fixed costs are not tax deductible, higher sales are necessary for outsourcing firms to break even. Taken together, some outsourcing firms exit the market, raising demand for the remaining firms. Eq. (16) shows that the associated loss of varieties overcompensates the decline in prices charged by MNEs.
} 
With this, we are in the position to prove our main result, which is that MNEs in equilibrium may shift profits abroad even when they perfectly comply with the tax rules that are widely perceived to prevent profit shifting.

To this end, we compare effective tax rates, which are defined as tax payment per unit of the tax base. For MNEs, the effective tax rate is given by

$$
t_{i}^{e f f}=\frac{t_{H}\left(p_{i}^{t}-r\right) x_{i}^{t}+t_{L}\left(r-a_{i}\right) x_{i}^{t}}{\left(p_{i}^{t}-a_{i}\right) x_{i}^{t}} .
$$

The effective tax rate of outsourcing firms, $t_{o}^{e f f}$, is equal to $t_{H}$, as these firms have no opportunity to shift profits. The empirically low tax burden of MNEs, by which we motivated our paper, thus follows naturally from the sorting decision of MNEs:

Proposition 1 (Tax burden of MNEs). If profits are taxed at arm's length under an exemption system, MNEs face a lower tax burden relative to their profits than outsourcing firms, as is shown by the comparison of their effective tax rates: $t_{i}^{\text {eff }}<t_{o}^{\text {eff }}=$ $t_{H}$. The most productive firms face the lowest effective tax rate $\left(\frac{\partial t_{i}^{e f f}}{\partial a_{i}}>0\right)$.

Proof. See the appendix.

In an industry with heterogeneous firms, application of the arm's length principle implies a systematic misvaluation of transfer prices for MNEs. This is a consequence of firms' endogenous decisions about their organizational form. The potential for profit shifting is largest for the most productive firms, who benefit from the most pronounced difference between actual costs and the market-determined transfer price.

The opportunity to shift profits abroad (where they are taxed at a lower rate) induces additional integration at the margin, raising the mass of multinational firms beyond its no-tax benchmark. Formally, the mass of MNEs is given by $G\left(a_{t}^{*}\right)$, and $a_{t}^{*} \geq a^{*}$ (proof in the appendix).

As can be verified from eq. (17), the additional incentive to become a MNE is more pronounced when a high market price of the input allows for substantial profit shifting, or when a low foreign tax rate implies large gains from being partly taxed abroad. The latter effect is larger in magnitude if the domestic tax rate is already high to begin with. Similarly, gains from integration rise with the domestic tax rate; and this effect is stronger if the potential for profit shifting is high ( $r$ is large) or the associated gains are large $\left(t_{L}\right.$ is low $)$. 
While taxation induces additional firms to integrate, at the same time it reduces the total number of outsourcing firms. Formally, by solving the definition of the price index for $n_{o}^{t}$, the equilibrium number of domestic firms is now given by

$$
n_{o}^{t}=\frac{\mu}{\sigma c}\left(1-t_{H}\right)-\left[\frac{(1+\tau) r}{\tilde{a}^{t}\left(a_{t}^{*}\right)}\right]^{\sigma-1} .
$$

Here, $\tilde{a}^{t}$ defines a weighted average effective input coefficient under taxation; i.e., a measure of the average marginal cost when taking the distortion caused by the arm's length principle into account:

$$
\tilde{a}^{t}\left(a_{t}^{*}\right) \equiv\left[\int_{0}^{a_{t}^{*}}\left[\frac{1-t_{L}}{1-t_{H}} a_{i}-\frac{t_{H}-t_{L}}{1-t_{H}} r\right]^{-(\sigma-1)} d G(a)\right]^{-\frac{1}{\sigma-1}}
$$

Comparing equations (10) and (19), and noting that $\tilde{a}^{t}\left(a_{t}^{*}\right) \leq \tilde{a}\left(a^{*}\right)$, we find that $n_{o}^{t}<n_{o}$. Intuitively, the number of outsourcing firms falls for two reasons. First, some firms integrate that would buy the input on the market in the absence of taxes. In addition, some outsourcing firms exit the market because demand is shifted away from their varieties to products manufactured by multinationals who are induced to set lower prices by the taxation at arm's length.

The increase in the mass of MNEs cannot compensate the market exit by outsourcing firms. The change in the overall mass of firms can be seen in the change of the price index, which is a decreasing function of the total mass of active firms. As prices either do not change (outsourcing firms) or decrease (MNEs) due to taxation, the fact that $P_{t}>P$ (see eq. 16) thus implies that the overall mass of firms falls. We summarize these findings in the following proposition:

Proposition 2 (Composition and mass of active firms). Relative to a world without taxes, arm's length taxation under an exemption system leads to more multinationals and fewer outsourcing firms. Overall, the mass of firms (of available consumer products) falls.

Proof. See the appendix.

Next, we delve deeper into the effects of profit taxation on equilibrium prices and quantities, which we gather in the following proposition:

Proposition 3 (Price and quantity effects of arm's length taxation). Relative to the no-tax benchmark, arm's length taxation under an exemption 
system raises the equilibrium output/size of multinational and outsourcing firms, reduces the prices charged by MNEs, and leaves the prices charged by outsourcing firms unaffected. The price reduction by MNEs is more pronounced if the tax rate differential, the arm's length price, or the productivity of the MNE's subsidiary is higher.

Proof. See the appendix.

MNEs reduce consumer prices in response to taxation because of an additional effect in their profit maximization. Besides its impact on quantities, the pricing decision now also affects the firm's effective tax rate. This is because the share of profits taxed in the high-tax country is determined by the difference between the consumer price and the transfer price. Other things being equal, by lowering consumer prices, the MNE is able to shift a higher fraction of profits abroad and thus to raise after-tax profits.

The effect on prices is increasing in the tax rate differential $\left(t_{H}-t_{L}\right)$, which acts as a measure of the potential gains from profit shifting. Similarly, a high transfer price $r$ or - from a firm's perspective - possessing a low $a_{i}$ implies more opportunities to avoid profit taxes and thus leads to lower prices. These channels reinforce each other: the effect of a rise in $t_{H}$ (a fall in $t_{L}$ ) is larger if $t_{L}$ is low $\left(t_{H}\right.$ is high), or if $r$ is large.

Besides the change in prices, sales are affected by an equilibrium change in demand, as captured by the price index (see eq. (16)). The increase in the price level reinforces the direct effect of taxation, leading to higher sales of all surviving firms. Sales of MNEs increase by more than those of outsourcing firms, as the former actively set lower prices in order to benefit from the profit shifting possibilities which arise due to the arm's length principle. As sales of MNEs increase, and some outsourcing firms become MNEs, the tax system contributes to the rising importance of MNEs.

The main result of this section is the relatively low tax burden of MNEs, a fact well established in the empirical literature. In contrast to this article, the focus usually is on tax evasion possibilities within MNEs. ${ }^{26}$ Being a multinational corporation is, after all, the prerequisite for most tax avoidance strategies, as it enables firms to shift profits into low-tax countries. A major possibility for MNEs to actively reduce tax payments is by mispricing cross-border transactions. Explanations based on such transfer price

\footnotetext{
${ }^{26}$ See e.g. Haufler and Schjelderup (2000) or Egger and Seidel (2010).
} 
manipulations are complementary to the implicit profit shifting that results from the optimal organization of production. In the following section we provide a link to the literature on transfer price manipulation by including this practice in our model and discuss some of our key assumptions.

\subsection{Extension to transfer price manipulation and discussion}

Allowing for transfer price manipulation, the profit function of a MNE is equal to

$$
\pi_{i}^{m}=\left(1-t_{H}\right)\left[p_{i}^{m}-(1+\delta) r\right] x_{i}^{m}+\left(1-t_{L}\right)\left[(1+\delta) r-a_{i}\right] x_{i}^{m}-c-f-\delta^{2} \gamma x_{i}^{m},
$$

where $\delta$ measures the extent of transfer price manipulation and $\gamma$ is a factor that scales the cost of tax evasion. Manipulating the transfer price comes at a convex cost, which we presume, for simplicity, to have quadratic form. ${ }^{27}$ Our analysis in the previous section is thus the limiting case where $\gamma \rightarrow \infty$.

MNEs now maximize profits by choosing both the amount of tax evasion $(\delta)$ and their price $\left(p_{i}^{m}\right)$. This yields

$$
\begin{gathered}
\delta=\frac{1}{2 \gamma}\left(t_{H}-t_{L}\right) r, \\
p_{i}^{m}=\frac{\sigma}{\sigma-1}\left(\frac{1-t_{L}}{1-t_{H}} a_{i}-\frac{t_{H}-t_{L}}{1-t_{H}} r-\frac{\frac{1}{4 \gamma}\left(t_{H}-t_{L}\right)^{2}}{1-t_{H}} r^{2}\right)<p_{i}^{t} .
\end{gathered}
$$

Given the option to manipulate transfer prices, MNEs further reduce consumer prices, since the amount of tax they can evade increases with each unit sold. This effect is stronger when the cost of transfer price manipulation $\gamma$ is low, or the statutory transfer price $r$ is high. The optimal degree of transfer price manipulation equates the marginal cost of transfer price manipulation, $2 \delta \gamma$, with its benefits, $\left(t_{H}-t_{L}\right) r$, which are increasing in the tax rate differential and the arm's length price of the input.

Because being a multinational allows firms to evade taxes by transfer price manipulation, organizing as a MNE becomes more attractive. Therefore, the cost cutoff for vertical integration rises:

$$
a_{m}^{*}=\frac{1-t_{H}}{1-t_{L}}(1+\tau) r\left(\frac{c}{c+f}\right)^{\frac{1}{\sigma-1}}+\frac{t_{H}-t_{L}}{1-t_{L}} r+\frac{\frac{1}{4 \gamma}\left(t_{H}-t_{L}\right)^{2}}{1-t_{L}} r^{2}>a_{t}^{*} .
$$

${ }^{27}$ This way of modeling transfer price manipulation follows Egger and Seidel (2010). 
More firms integrate if the cost of transfer price manipulation is low or if the gains are high (high tax rate difference and/or high $r$ ).

We summarize the added implications of transfer price manipulation in the following proposition:

Proposition 4 (Implications of transfer price manipulation). If multinational firms can manipulate transfer prices: i) more firms choose to organize as multinationals, and ii) consumer prices of products sold by MNEs fall.

It is valuable to distinguish between the manipulation of transfer prices and the effect of taxation at a gorilla's arm's length, even though the implications for firm behavior are similar, because the policy conclusions differ. Importantly, we find that tightening transfer price regulations (increasing $\gamma$ ) may help to reduce tax evasion, but cannot be expected to even out the tax burden between domestic and multinational firms.

We conclude our analysis by briefly discussing the robustness of our main results with respect to some basic assumptions. First, we have employed a highly simplified production structure, where final good production at a MNE's headquarter is modeled exclusively via fixed costs $(c)$. This, however, is innocuous: Under a more elaborate production structure, including a potentially firm-specific production function, the effect of taxation at a gorilla's arm's length remains present as long as the MNE is more productive than the market in input production, which takes place abroad.

Second, we have focussed on MNEs whose headquarters are located in the high-tax country. But what about final good producers located in the low-tax country? Consider their alternatives for procuring the input: They can either buy it from the market, or produce it in a subsidiary either at home or abroad. However, given that the other country offers the same wage (i.e. identical production cost) but has a higher tax rate, firms in the low-tax country have no incentive to become a MNE, they instead produce the input in a subsidiary at home. ${ }^{28}$ The case in our model - with MNEs being headquartered in high-tax countries in Europe or in Japan - is also empirically the most relevant, see Voget (2011).

\footnotetext{
${ }^{28}$ For the same reason (i.e. the tax difference being the only rationale of going abroad), final good producers in the high-tax country never open a subsidiary at home.
} 
Third, in the model, we do not say much about the production of inputs on the market. We envision a perfectly competitive sector which is specialized in the production of generic inputs, and independent from the final good producers. One may ask why the final good producer that is most productive in input production does not enter and take over that market. Many reasons are conceivable, e.g. capacity constraints. In our model, a non-specific variant of the input is sold on the market. We therefore imply that the MNEs' advantage lies only in the production of the customized input, not in input production in general. Even the most productive firm may therefore be less efficient in the production of a non-specific input (which then could be used by other firms) than the market, as there are costs of transforming the firm-specific input into a version that can be used by other firms. ${ }^{29}$ In short, taxation at a gorilla's arm's length occurs when inputs sold on the market are more expensive or less suited for final good production than custom-made inputs for at least some firms.

\section{Conclusion}

The goal of this paper has been to provide a new explanation why MNEs face lower effective tax rates than domestic firms. Based on recent developments in the international economics literature, which established that the most productive firms in the economy become multinationals, we argued that sorting according to firm productivity has important implications for taxation. Transfer prices are determined by market prices even though these firms have chosen to become multinationals precisely because they are better at input production than the market. Therefore, the arm's length principle, which prescribes the use of market prices, implies transfer prices that systematically exceed marginal cost, thus allowing MNEs to shift profits abroad.

With this article, we hope to contribute to explaining why MNEs pay systematically

\footnotetext{
${ }^{29}$ Furthermore, it is doubtful whether the most productive firm has an incentive to enter even in the absence of such costs. As firm productivities are drawn from a continuous distribution, it would not be able to charge monopoly prices (or a limit price just below $r$ ), as this would induce entry by other firms. In equilibrium, it would set a price of the input equal to its marginal cost, therefore making no profits in this market. As it would simultaneously decrease input costs for the other final good producers, it would also cannibalize its profits in the final goods market. Therefore, the most productive firm does not have an incentive to enter.
} 
less tax than domestic firms. Focussing on the endogenous organizational choice of international enterprises, our model complements existing mechanisms for profit shifting, which usually build on the notion that MNEs are able to manipulate transfer prices. In our framework, profit shifting occurs even when MNEs perfectly comply with the tax code. The fact that transfer price regulation has tightened substantially over the last decades, while tax burden differentials between MNEs and domestic firms appear to remain substantial, seems to support this view. 


\section{Appendix}

\section{Proof of Proposition 1: Tax burden of MNEs.}

By contradiction: Suppose to the contrary that $t_{i}^{\text {eff }}>t_{H}$. Then,

$$
\frac{t_{H}\left(p_{i}^{t}-r\right) x_{i}^{t}+t_{L}\left(r-a_{i}\right) x_{i}^{t}}{\left(p_{i}^{t}-a_{i}\right) x_{i}^{t}}>t_{H} \Leftrightarrow\left(t_{H}-t_{L}\right)\left(r-a_{i}\right)<0,
$$

a contradiction as $t_{H}>t_{L}$ and $r \geq a_{i}$ for all $a_{i} \leq a_{t}^{*}$, since $r \geq a_{t}^{*}$. To see the latter, we need to verify that

$$
r \geq a_{t}^{*}=\frac{1-t_{H}}{1-t_{L}}(1+\tau) r\left(\frac{c}{c+f}\right)^{\frac{1}{\sigma-1}}+\frac{t_{H}-t_{L}}{1-t_{L}} r .
$$

Assumption (7) states that $\tau$ is bounded above by $\tau \leq\left(\frac{c+f}{c}\right)^{\frac{1}{\sigma-1}}-1$. In the case where (7) holds with equality, $(1+\tau)\left(\frac{c}{c+f}\right)^{\frac{1}{\sigma-1}}=1$. In this case, $a_{t}^{*}=\frac{1-t_{H}}{1-t_{L}} r \cdot 1+\frac{t_{H}-t_{L}}{1-t_{L}} r=r$. If (7) holds with inequality, then $(1+\tau)\left(\frac{c}{c+f}\right)^{\frac{1}{\sigma-1}}<1$, and thus $r>a_{t}^{*}$.

To prove the systematic relationship between the tax burden and the productivity of MNEs, we need to sign

$$
\frac{\partial t_{i}^{e f f}}{\partial a_{i}}=\frac{\left(t_{H} \frac{\partial p_{i}^{t}}{\partial a_{i}}-t_{L}\right)\left(p_{i}^{t}-a_{i}\right)-\left(t_{H} p_{i}^{t}-t_{H} r+t_{L} r-t_{L} a_{i}\right)\left(\frac{\partial p_{i}^{t}}{\partial a_{i}}-1\right)}{\left(p_{i}^{t}-a_{i}\right)^{2}},
$$

which carries the same sign as

$$
\left(t_{H}-t_{L}\right)\left(p_{i}^{t}-r+\left(r-a_{i}\right) \frac{\partial p_{i}^{t}}{\partial a_{i}}\right)=\left(t_{H}-t_{L}\right) \frac{r}{\sigma-1}>0,
$$

where the last equality uses eq. (14).

\section{Proof of Proposition 2: Composition and mass of active firms.}

To show that $a_{t}^{*} \geq a^{*}$, we need to verify from equations (9) and (17):

$$
\frac{1-t_{H}}{1-t_{L}}(1+\tau) r\left(\frac{c}{c+f}\right)^{\frac{1}{\sigma-1}}+\frac{t_{H}-t_{L}}{1-t_{L}} r \geq\left(\frac{c}{c+f}\right)^{\frac{1}{\sigma-1}}(1+\tau) r
$$

Rearranging shows that $a_{t}^{*} \geq a^{*}$ if and only if $\frac{1-t_{H}}{1-t_{L}}+\frac{t_{H}-t_{L}}{1-t_{L}}\left(\frac{c+f}{c}\right)^{\frac{1}{\sigma-1}} \frac{1}{1+\tau} \geq 1$, which always holds under assumption (7) as $t_{L}<t_{H}$. 
Proof of Proposition 3: Price and quantity effects of arm's length taxation.

For each firm, the price change due to taxation at arm's length is equal to

$$
\Delta_{p}\left(a_{i}\right) \equiv p_{t}\left(a_{i}\right)-p\left(a_{i}\right)=-\frac{\sigma}{\sigma-1} \frac{t_{H}-t_{L}}{1-t_{H}}\left(r-a_{i}\right)
$$

Using (7), $\Delta_{p}\left(a_{i}\right) \leq 0$, since $r \geq a_{i}$ for all $a_{i} \leq a^{*}$. The effect on quantities follows from comparing equilibrium values under taxation with the benchmark case. Inspection of (27) completes the proof. 


\section{References}

Antràs, P., 2003. Firms, contracts, and trade structure. Quarterly Journal of Economics $118,1375-1418$.

Antràs, P., Helpman, E., 2004. Global sourcing. Journal of Political Economy 112, $552-580$.

Baldwin, R., Okubo, T., 2009. Tax reform, delocation and heterogeneous firms. Scandinavian Journal of Economics 111, 741-764.

Bernard, A.B., Jensen, J.B., Redding, S.J., Schott, P.K., 2010. Intrafirm trade and product contractibility. American Economic Review 100, 444-448.

Buettner, T., Overesch, M., Schreiber, U., Wamser, G., 2009. Taxation and capital structure choice - evidence from a panel of German multinationals. Economics Letters 105, 309-311.

Chor, D., 2009. Subsidies for FDI: Implications from a model with heterogeneous firms. Journal of International Economics 78, 113-125.

Clausing, K., 2003. Tax-motivated transfer pricing and US intrafirm trade prices. Journal of Public Economics 87, 2207-2223.

Cole, M.T., Davies, R.B., 2011. Optimal tariffs, tariff jumping, and heterogeneous firms. European Economic Review 55, 480-496.

Desai, M., Foley, F., Hines, J., 2006. The demand for tax haven operations. Journal of Public Economics 90, 513-531.

Deutsche Bundesbank, 2011. Statistische Sonderveröffentlichung 6. Verhältniszahlen aus Jahresabschlüssen deutscher Unternehmen von 2007 bis 2008.

Devereux, M.P., 2007. The Impact of Taxation on the Location of Capital, Firms and Profit: a Survey of Empirical Evidence. Working Paper 07/02. Oxford University Centre for Business Taxation.

Devereux, M.P., Keuschnigg, C., 2009. The Distorting Arm's Length Principle. Working Paper 09/10. Oxford University Centre for Business Taxation. 
Dischinger, M., Riedel, N., 2011. Corporate taxes and the location of intangible assets within multinational firms. Journal of Public Economics 95, 691-707.

Dixit, A.K., Stiglitz, J.E., 1977. Monopolistic competition and optimum product diversity. American Economic Review 67, 297-308.

Egger, P., Eggert, W., Keuschnigg, C., Winner, H., 2010a. Corporate taxation, debt financing and foreign-plant ownership. European Economic Review 54, 96-107.

Egger, P., Eggert, W., Winner, H., 2010b. Saving taxes through foreign plant ownership. Journal of International Economics 81, 99-108.

Egger, P., Seidel, T., 2010. Corporate taxes and intra-firm trade. Mimeo, ETH Zurich.

Elitzur, R., Mintz, J., 1996. Transfer pricing rules and corporate tax competition. Journal of Public Economics 60, 401-422.

Gresik, T., Osmundsen, P., 2008. Transfer pricing in vertically integrated industries. International Tax and Public Finance 15, 231-255.

Grossman, G.M., Helpman, E., 2002. Integration versus outsourcing in industry equilibrium. Quarterly Journal of Economics 117, 85-120.

Grossman, G.M., Helpman, E., 2005. Outsourcing in a global economy. Review of Economic Studies 72, 135-159.

Grossman, G.M., Helpman, E., Szeidl, A., 2006. Optimal integration strategies for the multinational firm. Journal of International Economics 70, 216-238.

Gumpert, A., Hines, J., Schnitzer, M., 2011. The use of tax havens in exemption regimes. Mimeo, University of Munich.

Haufler, A., Schjelderup, G., 2000. Corporate tax systems and cross country profit shifting. Oxford Economic Papers 52, 306-325.

Head, K., Ries, J., 2003. Heterogeneity and the FDI versus export decision of japanese manufacturers. Journal of the Japanese and International Economies 17, 448-467.

Helpman, E., Melitz, M.J., Yeaple, S.R., 2004. Export versus FDI with heterogeneous firms. American Economic Review 94, 300-316. 
Huizinga, H., Laeven, L., 2008. International profit shifting within multinationals: A multi-country perspective. Journal of Public Economics 92, 1164-1182.

Janeba, E., 1996. Foreign direct investment under oligopoly: Profit shifting or profit capturing? Journal of Public Economics 60, 423-445.

Krautheim, S., Schmidt-Eisenlohr, T., 2011. Heterogeneous firms, 'profit shifting' FDI and international tax competition. Journal of Public Economics 95, 122-133.

Krugman, P., 1980. Scale economies, product differentiation, and the pattern of trade. American Economic Review 70, 950-959.

Lorz, O., Wrede, M., 2008. Standardization of intermediate goods and international trade. Canadian Journal of Economics 41, 517-536.

Melitz, M.J., 2003. The impact of trade on intra-industry reallocations and aggregate industry productivity. Econometrica 71, 1695-1725.

Spencer, B., 2005. International outsourcing and incomplete contracts. Canadian Journal of Economics 38, 1107-1135.

Tomiura, E., 2007. Foreign outsourcing, exporting and FDI: A productivity comparison at the firm level. Journal of International Economics 72, 113-127.

Voget, J., 2011. Relocation of headquarters and international taxation. Journal of Public Economics 95, 1067-1081. 